\title{
Hubungan antara Perubahan Indeks Massa Tubuh (IMT) dengan Respon Kemoterapi Neoadjuvan Kombinasi Doksorubisin pada Penderita Kanker Payudara Lanjut Lokal di RSUP Dr. Hasan Sadikin Bandung
}

\author{
Kiki Budiani. $\mathrm{S}^{1}$, Maman Abdurahman², Kiki A. Rizki ${ }^{2}$ \\ ${ }^{1}$ Departemen Bedah, Universitas Padjadjaran, Bandung \\ ${ }^{2}$ Departemen Bedah Onkologi, Universitas Padjadjaran, Bandung
}

\begin{abstract}
Abstrak
Latar Belakang. Kanker payudara merupakan kanker dengan insidensi tertinggi pada wanita di Indonesia. Kemoterapi saat ini merupakan salah satu modalitas terapi yang digunakan dalam penatalaksanaan kanker payudara. Salah satu regimen yang paling banyak digunakan adalah Doksorubisin. Perubahan berat badan selama kemoterapi dapat berhubungan dengan prognosis yang buruk pada pasien kanker baik itu kenaikan berat badan ataupun penurunan berat badan. Tujuan. Mengetahui hubungan antara perubahan indeks massa tubuh (IMT) dengan respon kemoterapi pada penderita kanker payudara lanjut lokal yang telah menjalani kemoterapi neoadjuvan kombinasi Doksorubisin 6 siklus.

Metode. Rancangan penelitian ini menggunakan desain penelitian observasional analitik cross-sectional prospektif yaitu untuk mengetahui pengaruh perubahan indeks massa tubuh (IMT) terhadap respon kemoterapi neoadjuvan kombinasi Doksorubisin pada penderita kanker payudara lanjut lokal. Penelitian dilakukan di Poliklinik Bedah Onkologi dan ruang rawat inap Rumah Sakit Umum Pusat Dr. Hasan Sadikin Bandung periode April 2019 sampai dengan Agustus 2019. Pasien kanker payudara yang akan menjalani kemoterapi dengan regimen Doksorubisin dilakukan pemeriksaan berat badan, tinggi badan, dan ukuran tumor di awal siklus, setelah follow up 6 siklus kemoterapi diukur kembali berat badan, tinggi badan, dan ukuran tumor kemudian dinilai respon kemoterapi.
\end{abstract}

Hasil. Didapatkan hasil untuk kelompok dengan respon kemoterapi sebanyak 49 atau sebesar $81,7 \%$ dan kelompok tidak respon sebanyak 11 atau sebesar 18,3\%. Rata-rata usia pasien adalah 47,9 $\pm 8,79$ dengan stadium IIIA sebanyak 27 atau sebesar 45,0\% dan IIIB sebanyak 33 atau sebesar 55,0\%. Untuk IMT awal memiliki rata-rata sebesar $25,9 \pm 4,00$, dengan kategori 


\section{ARTIKEL PENELITIAN}

berat badan kurang sebanyak 3 atau sebesar 5,0\%, kisaran normal sebanyak 13 atau sebesar $21,7 \%$, berisiko sebanyak 14 atau sebesar $23,3 \%$, obesitas tingkat I sebanyak 27 atau sebesar 45,0\% dan obesitas tingkat II sebanyak 3 atau sebesar 5,0\%. Untuk perubahan IMT memiliki rata-rata sebesar $-1,04 \pm 1,719 \mathrm{~kg} / \mathrm{m}^{2}$. Terdapat perubahan berat badan pada kedua kelompok yaitu pada kelompok respon, BB berkurang sebanyak 35 atau sebesar 71,.4\%, BB tetap sebanyak 5 atau sebesar 10,2\% dan BB bertambah sebanyak 9 atau sebesar 18,4\%.Pada kelompok tidak respon, kategori BB berkurang sebanyak 5 atau sebesar 45,5\%, BB tetap sebanyak 3 atau sebesar 27,3\% dan BB bertambah sebanyak 3 atau sebesar 27,3\%.

Kesimpulan. Perubahan Indeks Massa Tubuh (IMT) tidak menunjukkan kemaknaan terhadap respon kemoterapi maka dapat disimpulkan perubahan IMT tidak berpengaruh terhadap respon kemoterapi pada penderita kanker payudara lanjut lokal yang menjalani kemoterapi neoadjuvan kombinasi Doksorubisin.

(ISSN 2723-7494 J Bedah Indonesia. 2020;48:3-21)

Kata kunci : IMT, kanker payudara, doksorubisin, respon kemoterapi

Korespondensi penulis:

Kiki Budiani

Departemen Bedah, Universitas Padjadjaran, Bandung

Jalan Pasteur no. 38, Pasteur, Sukajadi, Bandung

Email : drqieki8206@gmail.com 


\title{
The Relationship between Changes in Body Mass Index (BMI) with Response of Neoadjuvant Chemotherapy Combination of Doxorubicin in Local Advanced Breast Cancer Patients at Dr. Hasan Sadikin Bandung Hospital
}

\author{
Kiki Budiani. S ${ }^{1}$, Maman Abdurahman², Kiki A. Rizki² \\ ${ }^{1}$ Surgery Department, Universitas Padjadjaran, Bandung \\ 2 Department of Oncology Surgery, Universitas Padjadjaran, Bandung
}

\begin{abstract}
Background. Breast cancer is one form of cancer with the highest incidence in women in Indonesia. Chemotherapy is one of the therapeutic modalities used in the management of breast cancer. One of the most widely used regimens is Doxorubicin. Changes in body weight during chemotherapy can be associated with a poor prognosis in cancer patients whether it is weight gain or weight loss.

Objective. To determine the relationship between changes in body mass index (BMI) with chemotherapy responses in patients with locally advanced breast cancer who have undergone 6-cycle combination of Doxorubicin neoadjuvant chemotherapy.

Methods. Design of this study was a prospective cross sectional with an analytical observational study to determine the effect of changes in body mass index (BMI) with responses to neoadjuvant chemotherapy of Doxorubicin in locally advanced breast cancer patients. The study was conducted at the Surgical Oncology Polyclinic and chemotherapy ward of Dr. Hasan Sadikin Hospital Bandung from April to August 2019. Breast cancer patients who underwent Doxorubicin chemotherapy were examined for body weight, height and tumor size at the beginning of the cycle and after 6 cycles of chemotherapy.

Result. The results for the group with chemotherapy response were 49 or $81.7 \%$ and the nonresponse group were 11 or $18.3 \%$. The average age of the patients was $47.9 \pm 8.79$, with Stage IIIA 27 or $45.0 \%$ and IIIB 33 or 55.0\%. The initial BMI had an average of $25.9 \pm 4.00$, with a category of underweight 3 or $5.0 \%$, a normal range of 13 or $21.7 \%$, a risk of 14 or $23.3 \%$, obesity level I as much as 27 or $45.0 \%$ and obesity level II as much as 3 or by $5.0 \%$. The change in BMI has an average of $-1.04 \pm 1.719 \mathrm{~kg} / \mathrm{m} 2$. There were changes in body weight in both groups, in the Response group, reduced weight were 35 or $71.4 \%$, remained weight were 5 or $10.2 \%$ and increased weight were 9 or $18.4 \%$. In the No response group, reduced weight were 5 or $45.5 \%$, remained weight were 3 or $27.3 \%$ and increased weight were 3 or $27.3 \%$.

Conclusion. Changes in Body Mass Index (BMI) did not significantly affect the responses of chemotherapy in patients with local advanced breast cancer undergoing Doxorubicin neoadjuvant chemotherapy.
\end{abstract}

Keywords : BMI, breast cancer, doxorubicin, chemotherapy response 


\section{ARTIKEL PENELITIAN}

\section{Latar Belakang}

Kanker payudara merupakan masalah global dan isu kesehatan internasional yang penting. Kanker payudara adalah keganasan paling sering pada wanita di negara maju dan nomer dua setelah kanker servik di negara berkembang dan merupakan 29\% dari seluruh kanker yang didiagnosa tiap tahun. ${ }^{1}$

Menurut data Global Burden of Cancer Study (GLOBOCAN) yang dikeluarkan oleh International Agency for Research on Cancer (IARC) tahun 2012, diketahui bahwa kanker payudara merupakan penyakit kanker dengan persentase kasus baru tertinggi, yaitu sebesar $43,3 \%$ dan persentase kematian akibat kanker payudara sebesar 12,9\% (Depkes RI, 2015). ${ }^{2,3}$

Diperkirakan 519.000 orang wanita meninggal akibat kanker payudara dan sebanyak 69\% kematian tersebut di negara yang sedang berkembang.

Menurut Sistem Informasi Rumah Sakit (SIRS) di Indonesia tahun 2007, diketahui bahwa kanker payudara menempati urutan pertama pasien rawat inap $(16,85 \%)$ dan pasien rawat jalan $(21,69 \%)$. Selain angka kejadian yang tinggi, kanker payudara juga memiliki angka mortalitas yang tinggi.
Tingginya angka kejadian dan mortalitas yang diakibatkannya membuat kanker payudara menjadi salah satu masalah kesehatan yang menarik perhatian dunia. ${ }^{4,5,6}$

Di Indonesia kanker payudara merupakan kanker dengan insiden tertinggi nomer satu dan terdapat kecenderungan dari tahun ke tahun insidennya meningkat. Sebagian besar keganasan payudara datang pada stadium lanjut. Muchlis Ramli dkk pada penelitiannya di RSCM mendapatkan stadium IIIA dan IIIB sebanyak 43.3\%, stadium IV sebanyak $14,3 \%$, berbeda dengan negara maju dimana kanker payudara ditemukan lebih banyak dalam stadium dini. Ini mungkin karena kurangnya informasi, letak geografis, pendidikan, banyaknya iklan yang menerangkan tentang pengobatan alternatif, kurangnya alat diagnostik seperti mammografi, USG dan kurangnya keterampilan tenaga medis dalam mendiagnosis kanker payudara. ${ }^{1}$

Pengobatan kanker payudara bertujuan untuk mendapatkan kesembuhan yang tinggi dengan kualitas hidup yang baik. Terdapat beberapa modalitas non pembedahan yang dikenal dalam penanganan kanker payudara yaitu kemoterapi, radioterapi, terapi biologis, dan 


\section{ARTIKEL PENELITIAN}

terapi hormonal. Dari beberapa modalitas tersebut, kemoterapi merupakan terapi yang berkembang pesat dalam tatalaksana kanker. ${ }^{7,8}$

Kemoterapi merupakan obat pembunuh sel kanker yang diberikan melalui jalur intravena atau peroral dan dapat diberikan setelah dilakukan pembedahan (kemoterapi adjuvan) dan sebelum dilakukan pembedahan (kemoterapi neoadjuvan). Pada awalnya kemoterapi digunakan dalam regimen tunggal. Seiring berkembangnya penelitian, terapi dengan regimen kombinasi menjadi pilihan pada saat ini. Terapi kombinasi ini memiliki tingkat respon yang lebih tinggi dibandingkan regimen tunggal. Salah satu obat kemoterapi yang efektif dalam terapi kanker payudara adalah golongan antrasiklin. ${ }^{7,8}$

Antrasiklin merupakan golongan antibiotik yang memiliki efektivitas tinggi dalam penanganan sel-sel kanker, baik kanker hematologi maupun kanker solid, termasuk kanker payudara. Obat-obatan yang termasuk dalam golongan antrasiklin antara lain Doksorubisin, Daunorubisin, Epirubisin, dan Idarubisin..$^{7,8,9}$ Doksorubisin merupakan salah satu obat dari golongan antrasiklin yang paling sering digunakan pada kemoterapi kombinasi kanker payudara.

Penelitian lain menyebutkan penambahan berat badan lebih banyak pada wanita premenopause, wanita yang mendapatkan kemoterapi dan wanita yang overweight saat didiagnosa. Kenaikan berat badan $>5.9 \mathrm{~kg}$ setelah diagnosa berhubungan dengan risiko tinggi kematian karena kanker payudara. ${ }^{10}$

Usia, ukuran tumor, status kelenjar getah bening aksila, tipe histologis tumor dan grade patologi merupakan faktor prognosis pada kanker payudara. Beberapa penelitian melaporkan hubungan antara overweight dan obesitas pada diagnosis kanker payudara dan prognosis buruk dengan tingginya rekurensi dan mortalitas. Beberapa penelitian melaporkan bahwa penambahan berat badan setelah terkena kanker payudara dapat berperan pada efek dari beberapa regimen terapi. ${ }^{12}$ Walaupun beberapa penelitian memperlihatkan peningkatan risiko kematian kanker payudara dalam era moden dari kemoterapi adjuvan berbasis antrasiklin dan taxan, hubungan antara indeks massa tubuh dan rekurensi serta kematian karena kanker payudara membutuhkan penelitian lebih lanjut dan hubungan dengan subtipe patologis, yaitu reseptor estrogen (ER)/ 


\section{ARTIKEL PENELITIAN}

progesteron (PR) positif, HER2 negatif, positif, dan triple negatif. ${ }^{13}$

Beberapa penelitian lain mengamati efek dari perubahan berat badan pada prognosis pasien kanker payudara yang mendapatkan kemoterapi dan hormonal terapi. Penelitian ini melaporkan peningkatan rekurensi dan kematian karena kanker payudara dan mortalitas total pada pasien yang mengalami perubahan berat badan lebih dari $2 \mathrm{~kg} / \mathrm{m}^{2}$ dibandingkan pasien yang menjaga berat badannya. Penggunaan kemoterapi berbasis antrasiklin dilaporkan berhubungan dengan perubahan berat badan dan overall survival atau disease free-survival. ${ }^{12}$

Sedangkan beberapa penelitian yang dilakukan sebelumnya melaporkan selama observasi tidak ada perubahan berat badan selama kemoterapi yang mengandung antrasiklin yang telah dikenal sebagai gold standard untuk terapi kanker payudara. Ini merupakan bukti bahwa perubahan berat badan selama kemoterapi dapat berhubungan dengan prognosis yang buruk pada pasien kanker baik itu kenaikan berat badan ataupun penurunan berat badan. ${ }^{12}$

Tetapi penelitian yang mencari tentang hubungan perubahan indeks massa tubuh (IMT) dengan respon kemoterapi neoadjuvan kombinasi doksorubisin (regimen FAC) belum banyak dilakukan, terutama di Indonesia.

Untuk pasien dengan stadium lanjut lokal (stadium IIIA, IIIB, IIIC) dianjurkan kemoterapi neoadjuvan , 3 siklus sebelum operasi dan 3 siklus pasca operasi. Kemoterapi neoadjuvan adalah pemberian kemoterapi pada penderita kanker dengan high grade malignancy dan belum pernah mendapat tindakan lokal-regional dengan bedah atau radiasi. Kemoterapi neoadjuvan bertujuan untuk memperkecil ukuran tumor dan kontrol mikrometastasis, disamping itu kemoterapi neoadjuvan dapat memberikan informasi tentang respon kemoterapi. ${ }^{1}$

Penilaian respons terhadap kemoterapi neoadjuvan dapat diklasifikasikan menurut kriteria evaluasi respons pada tumor padat (RECIST), dengan kriteria sebagai berikut : Tidak ada bukti klinis tumor pada payudara dan kelenjar getah bening aksila didefinisikan sebagai respons lengkap (CR). Pengurangan dalam diameter massa tumor terbesar melebihi $30 \%$ dinilai sebagai respons parsial (PR). Pengurangan ukuran tumor kurang dari $30 \%$ atau meningkat hingga $20 \%$ pada diameter terbesar dianggap sebagai Penyakit stabil (SD). Tumor dengan kenaikan lebih dari 20 $\%$ pada diameter terbesar atau munculnya 


\section{ARTIKEL PENELITIAN}

nodul baru dianggap sebagai penyakit progresif (PD). ${ }^{15}$

Indeks massa tubuh (IMT) adalah ukuran berat yang disesuaikan dengan tinggi, dihitung sebagai berat dalam kilogram dibagi dengan kuadrat tinggi meter ( $\mathrm{kg} / \mathrm{m} 2)$. Meski IMT sering dianggap sebagai indikator kegemukan tubuh, itu adalah ukuran pengganti lemak tubuh karena bisa mengukur kelebihan berat badan ketimbang kadar lemak berlebih. IMT adalah ukuran pengganti lemak tubuh yang sederhana, murah, dan tidak invasif. Berbeda dengan metode lain, IMT hanya bergantung pada tinggi dan berat badan dan dengan akses ke peralatan yang tepat, individu dapat meminta IMT mereka diukur dan dihitung secara rutin dengan akurasi yang masuk akal. ${ }^{16}$ Pada Tabel 1 dapat dilihat kategori indeks massa tubuh untuk Asia Pasifik.

Kemoterapi memengaruhi penurunan energi ekspenditur (kecepatan metabolisme basal yang rendah, termogenesis, dan aktifitas fisik), dan perbedaan modifikasi dalam asupan diet (peningkatan nafsu makan atau penurunan nafsu makan akibat kemoterapi yang berhubungan dengan mual dan muntah) yang dapat mengarah ke penambahan ataupun penurunan berat badan tergantung kebiasaan diet dari pasien yang akan berpengaruh pada respon dari kemoterapi. Resistensi insulin dapat menjadi mekanisme umum yang menjelaskan prognosis buruk dari pasien yang mengalami kehilangan berat badan maupun penambahan berat badan. ${ }^{12,17}$

\section{Metode}

Rancangan penelitian ini menggunakan desain penelitian observasional analitik cross-sectional prospektif yaitu untuk mengetahui pengaruh perubahan indeks massa tubuh terhadap respon kemoterapi kombinasi doksorubisin pada penderita kanker payudara. Penelitian ini adalah penelitian observasional analitik dengan rancangan cross-sectional. Seluruh pasien yang telah memenuhi kriteria inklusi dan eksklusi akan dimasukkan sebagai subjek penelitian. Konsep Crossection study atau metode potong lintang adalah untuk mengukur variabel tergantung dan bebas pada waktu bersamaan. Jenis penelitian ini berusaha mempelajari dinamika hubungan antara faktor-faktor risiko dengan dampak atau efeknya. Faktor risiko dan dampak atau efeknya diobservasi pada saat yang sama, artinya setiap subyek penelitian diobservasi hanya satu kali saja dan faktor 


\section{ARTIKEL PENELITIAN}

risiko serta dampak diukur menurut keadaan atau status pada saat observasi.

\section{Hasil}

Penelitian dilakukan pada periode April 2019 sampai dengan Agustsus 2019, dengan 60 subjek yang masuk kriteria inklusi penelitian (Tabel 2). Dengan demikian didapatkan total subjek yang telah menjalani kemoterapi kombinasi doksorubisin sebanyak 6 siklus sebesar 60 subjek.

Tabel 4. Terdapat perubahan berat badan pada kedua kelompok terhadap respon kemoterapi. Pada kelompok Respon, pasien dengan perubahan berat badan kategori BB berkurang sebanyak 35 atau sebesar $71, .4 \%$, BB tetap sebanyak 5 atau sebesar 10,2\% dan BB bertambah sebanyak 9 atau sebesar $18,4 \%$.

Tabel 4. Pada kelompok Tidak Respon, pasien dengan perubahan berat badan kategori BB berkurang sebanyak 5 atau sebesar $45,5 \%$, BB tetap sebanyak 3 atau sebesar 27,3\% dan BB bertambah sebanyak 3 atau sebesar $27,3 \%$.

Tabel 4. Pada kedua kelompok terdapat subjek yang mengalami penurunan berat badan sebanyak $40(66,7 \%)$, berat badan tetap atau tidak mengalami perubahan sebanyak $8(13,3 \%)$ dan subjek yang mengalami kenaikan berat badan sebanyak 12 (20\%). Perubahan berat badan berkisar $1 \mathrm{~kg}-5 \mathrm{~kg}$, dan hanya ada 2 subjek yang mengalami perubahan berat badan lebih dari $10 \mathrm{~kg}$.

Tabel 6. Pada kelompok Respon, untuk pasien dengan perubahan IMT kategori $<2 \mathrm{~kg} / \mathrm{m}^{2}$ sebanyak 38 atau sebesar $77,6 \%$ dan $>=2 \mathrm{~kg} / \mathrm{m}^{2}$ sebanyak 11 atau sebesar $22,4 \%$.

Tabel 6. Pada kelompok Tidak Respon, Untuk pasien dengan perubahan IMT kategori $<2 \mathrm{~kg} / \mathrm{m}^{2}$ sebanyak 9 atau sebesar $81,8 \%$ dan $>=2 \mathrm{~kg} / \mathrm{m}^{2}$ sebanyak 2 atau sebesar $18,2 \%$.

Untuk analisis pada data kategorik di uji menggunakan uji Chi Square yaitu perubahan IMT. Hasil uji statistik pada kelompok penelitian diatas diperoleh informasi nilai $\mathrm{P}$ pada variabel perubahan IMT lebih besar dari 0,05 (nilai $\mathrm{P}>0,05$ ) yang berarti tidak signifikan atau tidak bermakna secara statistik.

\section{Pembahasan}

Selama periode penelitian didapatkan 60 pasien kanker payudara yang telah mendapatkan kemoterapi neoadjuvan kombinasi doksorubisin yang disertakan dalam penelitian Untuk pasien dengan IMT kategori berat badan kurang pada Tabel 2 


\section{ARTIKEL PENELITIAN}

sebanyak 3 atau sebesar 5,0\%, kisaran normal sebanyak 13 atau sebesar 21,7\%, berisiko sebanyak 14 atau sebesar 23,3\%, obesitas tingkat I sebanyak 27 atau sebesar 45,0\% dan obesitas tingkat II sebanyak 3 atau sebesar 5,0\%. Penelitian oleh Kogawa et al, didapatkan IMT awal rata-rata sebesar $27,9 \mathrm{~kg} / \mathrm{m}^{2}$ dengan kategori IMT normal sebanyak $31,5 \%$, overweight sebanyak $31,1 \%$ dan obesitas sebanyak 37,3\%. Hal ini berbeda karena didapatkan nilai tengah IMT yang lebih tinggi pada etnis Afrika Amerika. $^{18}$

Pada penelitian ini kedua kelompok yang menjalani kemoterapi neoadjuvan, terdapat variasi perubahan berat badan (BB). Terdapat perubahan berat badan pada kelompok respon Tabel 4, pasien dengan BB berkurang sebanyak 35 atau sebesar $71, .4 \%$, BB tetap sebanyak 5 atau sebesar 10,2\% dan BB bertambah sebanyak 9 atau sebesar 18,4\%. Tabel 4, pada kelompok Tidak Respon, terdapat pasien dengan BB berkurang sebanyak 5 atau sebesar 45,5\%, BB tetap sebanyak 3 atau sebesar 27,3\% dan BB bertambah sebanyak 3 atau sebesar 27,3\%. Penelitian oleh Kogawa et al, setelah kemoterapi neoadjuvan didapatkan perubahan kategori indeks massa tubuh paling banyak yaitu kategori obesitas, dimana pasien dengan obesitas menunjukkan Reccurent Free Survival(RFS) dan Overall Survival(OS) yang lebih buruk dibandingkan pasien dengan IMT normal dan overweight. ${ }^{18}$ Sedangkan penelitian oleh Thivat et al, didapatkan $31 \%$ pasien yang menjalani kemoterapi mengalami perubahan berat badan $>$ dari $5 \%$ berat badan awal dimana berhubungan dengan peningkatan risiko rekurensi dan kematian. ${ }^{12}$

Tabel 5. Pada penelitian ini didapatkan perubahan rata-rata IMT adalah $-1,14 \pm 1,744 \mathrm{~kg} / \mathrm{m}^{2}$ pada kelompok Respon kemoterapi dan rata - rata perubahan IMT adalah $-0,57 \pm 1,594$ $\mathrm{kg} / \mathrm{m}^{2}$ pada kelompok Tidak Respon dengan kategori IMT obesitas kelas 1 sebanyak 27 atau 45,0\% dan obesitas kelas II sebanyak 3 atau 5,0\%. Penelitian terdahulu menyatakan bahwa perubahan berat badan secara signifikan terjadi pada 50- $96 \%$ pasien kanker payudara yang menjalani kemoterapi. ${ }^{19}$ Perubahan berat badan dilaporkan bervariasi antara $2,5 \mathrm{~kg}-$ $6,2 \mathrm{~kg}$, dimana perubahan berat lebih dari $10 \mathrm{~kg}$ sangat jarang. Beberapa penelitian terkini oleh Van den Berg dan Winkels melaporkan perubahan berat badan lebih rendah $(35-85 \%)$ dimana perubahan berat 


\section{ARTIKEL PENELITIAN}

bervariasi antara 1,4 - 5,0 kg. Perubahan berat badan diperkirakan karena perbedaan tipe kemoterapi, ukuran sampel, status menopause, indeks massa tubuh awal, metode penelitian, waktu saat pengukuran berat badan, tahun publikasi, negara, dan kualitas penelitian. ${ }^{19}$ Pada penelitian ini kedua kelompok mengalami perubahan berat badan berkisar $1 \mathrm{~kg}-5 \mathrm{~kg}$, dan hanya ada 2 subjek yang mengalami perubahan berat badan lebih dari $10 \mathrm{~kg}$.

Tabel 2. Pada penelitian ini didapatkan jumlah pasien yang mengalami obesitas kelas 1 sebanyak 27 pasien $(45,0 \%)$ dan obesitas kelas 2 sebanyak 3 pasien (5,0\%), dan stadium IIIB sebanyak 33 orang (55\%) pada saat didiagnosis. Pada pasien yang obesitas terdapat kemungkinan tumor yang lebih besar pada stadium lanjut, dan dapat mempengaruhi adanya dosis kemoterapi yang tidak tepat yang berakibat berkurangnya efektifitas klinis kemoterapi. Perubahan berat badan setelah diagnosis kanker prognosisnya cenderung lebih buruk, kebanyakan wanita mengalami perubahan berat badan setelah terdiagnosis kanker, dimana beberapa penelitian menunjukkan perubahan berat badan terjadi pada $50 \quad-96 \%$ pasien. Perubahan metabolisme pasien, aktivitas fisik, dan intake diet diduga sebagai mekanisme terjadinya perubahan berat badan. ${ }^{20}$

Pada penelitian ini didapatkan tidak hanya penurunan berat badan tetapi ada beberapa pasien yang mengalami kenaikan berat badan selama menjalani kemoterapi. Hal ini konsisten dengan beberapa literatur yang menyebutkan kenaikan berat badan lebih jelas pada wanita premenopause. Kombinasi dari beberapa faktor tentu dapat berperan dalam hal ini termasuk tipe dari kemoterapi, lamanya perawatan, serta kegagalan ovarium dan perbedaan perilaku dan gaya hidup. ${ }^{18}$

Pada penelitian ini didapatkan variasi perubahan IMT, dimana IMT awal subjek dengan kategori berat badan kurang (Tabel 2) sebanyak 3 atau sebesar 5,0\%, kisaran normal sebanyak 13 atau sebesar 21,7\%, berisiko sebanyak 14 atau sebesar 23,3\%, obesitas tingkat I sebanyak 27 atau sebesar $45,0 \%$ dan obesitas tingkat II sebanyak 3 atau sebesar 5,0\% namun tidak berpengaruh terhadap respon kemoterapi neoadjuvan. Sesuai dengan literatur yang menyebutkan IMT awal sebagai variabel kontinu tidak signifikan berhubungan terhadap patologis respon komplit kemoterapi. ${ }^{21}$ Pada penelitian ini tidak dicantumkan data mengenai status 


\section{ARTIKEL PENELITIAN}

menopause, tipe imunohistokimia, latihan dan kebiasaan diet pasien, atau penggunaan hormon steroid lain yang dapat mempengaruhi perubahan berat badan dan meningkatkan resiko kanker payudara.

Penelitian ini tidak terlepas dari berbagai kekurangan yang dapat mempengaruhi hasil penelitian. Pada penelitian ini tidak disertakan status menopause, tipe imunohistokimia, dan kadar gula darah

\section{Kesimpulan}

Tidak terdapat hubungan antara perubahan indeks massa tubuh (IMT) dengan respon kemoterapi pada pasien kanker payudara lanjut lokal yang mendapatkan kemoterapi neoadjuvan kombinasi doksorubisin.

\section{Daftar Pustaka}

1. Suyatno, Pasaribu ET.Bedah Onkologi Diagnosis dan Terapi. Kanker Payudara.Jakarta: CV Sagung Seto. Edisi ke-2.2012. Hlm.45-71

2. Sobri FB, Azhar Y, Wibisana IGN.G, Rachman A. Manajemen Terkini Kanker Payudara. Depok:Media Aesculapius.Edisi ke-1 2017.Hlm.554.
3. Badan Penelitian dan Pengembangan Kesehatan Kementerian Kesehatan RI, Riset kesehatan dasar 2013. [Diunduh 05 August2016]. Melalui: www.depkes.go.id/resources/downloa d/general/Hasil20Riskedas202013.pdf

4. Jemal A, Tiwari R, Murray T, Siegel R, Ghafoor A, Ward E, et al. Cancer statistics 2008. CA Cancer J Clin. 2008 Mar-Apr; 58)2)/; 71-96.

5. World Health Organization. Breast cancer: prevention and control.2016. [Diunduh 05-08-2016]. Melalui:http://www.who.int/cancer/de tection/breastcancer/en/index1.html.

6. International Agency for Research on Cancer (IARC). Globocan 2008; Estimated Cancer Incidence, Mortality and Prevalence Worldwide. Lyon.2012.

7. Manuaba IBTW. Kanker Payudara. Panduan Penatalaksanaan Kanker Solid PERABOI 2010: Sagung Seto; 2010. Hlm.33-37.

8. Chalasani P. Breast Cancer Treatment and Management: Medscape;2017 [Diunduh 05-01-2018]. Melalui : https://emedicine.medscape.com/articl e/1947145-treatment.

9. Rahman AM, Yusuf SW, Ewer MS. Anthracycline-induced cardiotoxicity 


\section{ARTIKEL PENELITIAN}

and the cardiac-sparing effect of liposomal formulation. International Journal

of

Nanomedicine.2007;2(4):567-583.

10. Ruiz MP.,Tarifa CM, Goffin JJV, Friedman, Slingerland. Obesity and Adverse breast Cancer Risk and Outcome : Mechanicstic Insights and Strategies. cancerjournal.com.2017; volume 67. number 5 .

11. Brunicardi FC, Andersen DK, Billiar TR, Dunn DL, Hunter JG, Matthews JB, et al.The Breast. Schwartz's Principles of Surgery. Tenth edition.McGraw-Hill Education: United States.2015. p: 511-511

12. Thivat E,Throndel S, Lapirot $\mathrm{O}$, Abrial C, Gimbergues P, Gadea E, et al. Weight Change during chemotherapy changes the prognosis in non metastatic breast cancer for the worse. [Diunduh 17 November 2017 ]. Melalui:

http://www.biomed.central.com/14712407/10/648.

13. Pajares B, Pollan M, Martin M, Mackey JR, Lluch A, Gavila J, et al. Obesity and Survival in Operable Breast Cancer Patients Treated with Adjuvant Anthracyclines and Taxanes acording to Pathological Subtypes:a pooled
analysis.[Diunduh 17 November 2017].Melalui:http://breast-cancerresearch.com/content/15/6/R105

14. Anders CK, Johnson R, Litton J, Phillips $\mathrm{M}$, and Bleyer A. Breast cancer before age 40 years. http://www.ncbi.nlm.nih.gov/pmc/arti cles.

15. Therasse P, Arbuck SA, Eisenhauer EA.New Guidelines to Evaluate the Response to Treatment in Solid Tumors. Journal of the National Cancer Institute, Vol. 92, No. 3, February 2, 2000.

16. Thorn CF, Oshiro C, Marsh S, Boussard $\mathrm{TH}$, McLeod H, Klein TE, et al. Doxorubicin pathways: pharmacodynamics and adverse effects. Pharmacogenent Genomics.2011 July; 21(\&): 440-446

17. Centers for Disease Control and Prevention. Body Mass Index : Consideration for Practitioners References List. [diunduh 09 November 2017].

Melalui http://www.cdc.gov/healthyweight/ass essing/bmi/.

18. Indeks Massa Tubuh Menurut WHO dan Asia Pasifik. Melalui http://perawatankesehatan.com/indeks -massa-tubuh/ 


\section{ARTIKEL PENELITIAN}

19. What is Diabetes? Melalui: https:

//www.niddk.nih.gov/

healthinfomation/ diabetes/ overview/

What-is diabetes/ prediabetes-insulinresistance.

20. Van den Berg MMGA, Winkels RM, Kruif JThCM, Laarhoven HWMV, Visser M, Vries JHM, et al. Weight Change during Chemotherapy in Breast Cancer patients : a metaanalysis. BioMed Central. 2017. 17 : 259

21. Champ CE, Volek JS, Siglin J, Jin L, SImone NL, Weight Gain, Metabolic Syndrome, and Breast Cancer Recurrence: Are Dietary Recommendations Supported by the Data? International Journal of Breast Cancer. Volume 2012, Article ID 506868, 9 pages.

22. Kogawa T, Fujii T, Fouad TM, Liu DD, Harano K, Masuda H, et al. Impact of Change in Body Mass Index during Neoadjuvant Chemotherapy and Survival among Breast Cancer Subtypes. Breast Cance Research and Treatment. 2018 


\section{ARTIKEL PENELITIAN}

\section{Daftar Tabel}

Tabel 1. Kategori indeks massa tubuh untuk Asia Pasifik

\begin{tabular}{cc}
\hline Kategori & IMT $\left(\mathrm{kg} / \mathrm{m}^{2}\right)$ \\
\hline Berat badan kurang & $<18,5$ \\
Kisaran normal & $18,5-22,9$ \\
Berat badan lebih & $>23,0$ \\
Berisiko & $23,0-24,9$ \\
Obesitas tingkat I & $25,0-29,9$ \\
Obesitas tingkat II & $\geq 30,0$ \\
\hline
\end{tabular}

Dikutip dari Indeks Massa Tubuh menurut WHO dan Asia Pasifik ${ }^{21}$ 


\section{ARTIKEL PENELITIAN}

Tabel 2. Karakteristik subjek penelitian

\begin{tabular}{|c|c|}
\hline Variabel & $\mathrm{N}=60$ \\
\hline \multicolumn{2}{|l|}{ Usia (tahun) } \\
\hline Rerata \pm Simpangan baku & $47,9 \pm 8,79$ \\
\hline Nilai Tengah & 48,00 \\
\hline Rentang (min-maks) & $28,00-74,00$ \\
\hline \multicolumn{2}{|l|}{ Stadium } \\
\hline IIIA & $27(45.0 \%)$ \\
\hline IIIB & $33(55.0 \%)$ \\
\hline \multicolumn{2}{|l|}{ IMT Sebelum } \\
\hline Rerata \pm Simpangan baku & $25,9 \pm 4,00$ \\
\hline Nilai Tengah & 26,32 \\
\hline Rentang (min-maks) & $16,21-36,09$ \\
\hline \multicolumn{2}{|l|}{ IMT Sesudah } \\
\hline Rerata \pm Simpangan baku & $24,9 \pm 3,50$ \\
\hline Nilai Tengah & 25,04 \\
\hline Rentang (min-maks) & $16,88-32,45$ \\
\hline \multicolumn{2}{|l|}{ Kategori IMT } \\
\hline Berat badan kurang & $3(5,0 \%)$ \\
\hline Kisaran normal & $13(21,7 \%)$ \\
\hline Berisiko & $14(23,3 \%)$ \\
\hline Obesitas tingkat I & $27(45,0 \%)$ \\
\hline Obesitas tingkat II & $3(5,0 \%)$ \\
\hline
\end{tabular}




\section{ARTIKEL PENELITIAN}

Tabel 3. Perbandingan Karakteristik Subjek Penelitian berdasarkan Respon Kemoterapi.

\begin{tabular}{lccc}
\hline \multirow{2}{*}{ Variabel } & \multicolumn{2}{c}{ Respon Kemo } & Nilai P \\
\cline { 2 - 3 } & Respon & Tidak Respon & \\
\cline { 2 - 3 } & & $\mathbf{N}=\mathbf{1 1}$ & \\
Usia (tahun) & & & $\mathbf{0 , 1 4 7}$ \\
Rerata \pm Simpangan baku & $47,2 \pm 9,16$ & $51,4 \pm 6,02$ & \\
Nilai Tengah & 47,00 & 50,00 & \\
Rentang (min-maks) & $28,00-74,00$ & $43,00-60,00$ & \\
& & & $\mathbf{0 , 4 8 1}$ \\
Stadium & & $6(54,5 \%)$ & \\
IIIA & $21(42,9 \%)$ & $5(45,5 \%)$ & \\
IIIB & $28(57,1 \%)$ & & \\
& & & \\
\end{tabular}




\section{ARTIKEL PENELITIAN}

Tabel 4. Perubahan Berat Badan berdasarkan Respon Kemoterapi.

\begin{tabular}{|c|c|c|c|}
\hline \multirow[b]{2}{*}{ Variabel } & \multicolumn{2}{|c|}{ Respon Kemo } & \multirow[b]{2}{*}{ Nilai P } \\
\hline & $\begin{array}{l}\text { Respon } \\
\mathrm{N}=49\end{array}$ & $\begin{array}{c}\text { Tidak respon } \\
\qquad \mathrm{N}=11\end{array}$ & \\
\hline Perubahan Berat badan & & & 0,579 \\
\hline BB Berkurang & $35(71,4 \%)$ & $5(45,5 \%)$ & \\
\hline BB Tetap & $5(10,2 \%)$ & $3(27,3 \%)$ & \\
\hline BB Bertambah & $9(18,4 \%)$ & $3(27, .3 \%)$ & \\
\hline
\end{tabular}




\section{ARTIKEL PENELITIAN}

Tabel 5. Perbandingan IMT sebelum, IMT Sesudah dan Perubahan IMT berdasarkan Respon Kemoterapi.

\section{Respon Kemoterapi}

\begin{tabular}{lccc}
\multicolumn{1}{c}{ Variabel } & Respon & Tidak respon & Nilai P \\
& $\mathbf{N}=\mathbf{4 9}$ & $\mathbf{N = 1 1}$ & $\mathbf{0 , 7 6 7}$ \\
\hline IMT sebelum & $26,0 \pm 3,73$ & $25,6 \pm 5,22$ & \\
Rerata \pm Simpangan baku & 26,34 & 25,10 & \\
Nilai Tengah & $16,21-32,89$ & $18 ., 3-36,09$ & \\
Rentang (min-maks) & & & $\mathbf{0 , 8 7 7}$ \\
& & & \\
IMT sesudah & $24,8 \pm 3,33$ & $25,0 \pm 4,35$ & \\
Rerata \pm Simpangan baku & 24,99 & 25,10 & \\
Nilai Tengah & $16,88-32,45$ & $18,31-32,39$ & \\
Rentang (min-maks) & & & $\mathbf{0 , 1 1 5}$ \\
& & & \\
Perubahan IMT & $-8,56-2,13$ & $-0,57 \pm 1,594$ & \\
Rerata \pm Simpangan baku & & 0,00 & \\
Nilai Tengah & & $-3,70-0,92$ & \\
Rentang (min-maks) & & & \\
\hline
\end{tabular}




\section{ARTIKEL PENELITIAN}

Tabel 6. Perbandingan Kategori Perubahan IMT berdasarkan Respon Kemoterapi

\begin{tabular}{|c|c|c|c|}
\hline \multirow[b]{2}{*}{ Variabel } & \multicolumn{2}{|c|}{ Respon Kemo } & \multirow[b]{2}{*}{ Nilai $\mathbf{P}$} \\
\hline & $\begin{array}{l}\text { Respon } \\
\mathrm{N}=49\end{array}$ & $\begin{array}{c}\text { Tidak respon } \\
\qquad \mathrm{N}=11\end{array}$ & \\
\hline $\begin{array}{l}\text { Kategori Perubahan } \\
\text { IMT }\end{array}$ & & & 0,756 \\
\hline$<2 \mathrm{~kg} / \mathrm{m}^{2}$ & $38(77,6 \%)$ & $9(81,8 \%)$ & \\
\hline$>=2 \mathrm{~kg} / \mathrm{m}^{2}$ & $11(2,4 \%)$ & $2(18,2 \%)$ & \\
\hline
\end{tabular}

